Fig. 1. A 6 by 4 analysis of variance revealed a significant group effect $[F(3,20)=5.75$, $\mathrm{p}<.01]$, a significant trials effect $[F(5,100)=45.20, p<.01]$, and $a$ borderline Group by Trial interaction effect $[F(15,100)=2.01, \quad .10>p>.05] . \quad A$ Duncan's range test was then computed to make specific group comparisons on total number of lever presses. It was found that Group Observe was superior to all other groups, Group Shape was superior to the two control groups, and the two control groups did not differ significantly from each other.

\section{DISCUSSION}

The principal findings of the present investigation are: (a) using total trials to criterion, the observational technique produces performance rates equal to that produced by the shaping technique, and (b) using total number of lever presses, the observational technique produces significantly better performance than the shaping technique. These results are contrary to those of Powell et al, presumably because the present investigation optimized the visual process by using hooded rats along with several apparatus modifications. Also, it should be noted that the present data exhibit markedly smaller mean and variability measures than do the data of Powell et al, again presumably due to the $S$ and apparatus differences between the two studies.

The findings of the present investigation have potential implications for research in experimental methodology and theories of learning. First, regarding experimental methodology, observational learning may be used as an efficient method for training operant behavior without the time demands and manpower associated with shaping techniques. Second, regarding theories of learning, observational learning involves changes in performance without the involvement of a direct overt response or the occurrence of direct reinforcement. This phenomenon may pose problems for traditional S-R reinforcement theories of learning, but it is not necessarily incompatible with such an approach (Gewirtz \& Stingl, 1968).

Finally, two qualifying notes should be made. First, the performance increments in "Group Observe" may have been due to the interaction of the observation during the training phase with the direct experience during the testing phase. The study of "pure" observational learning, independent of direct experience, remains to be done. Second, the results of any study which attempts to compare observational learning with shaping learning will depend, at least in part, on the skill of the $E$ who does the shaping.

\section{REFERENCES}

CORSON, J. A. Observational learning of a lever pressing response. Psychonomic Science, 1967, 7, 197-198.

DAVIDSON, P. W., \& WALK, R. D. Differential visual depth discrimination of hooded as compared to albino rats. Psychonomic Science, $1969,5,207-208$.

GEWIRTZ, J. J., \& STINGLE, K. G. Learning of generalized imitation as the basis for identification. Psychological Review, 1968, 75 374-397.

GREENHUT, A.M. Visual distance discrimination in the rat. Journal of Experimental Psychology, $1954,47,148-152$.

LASHLEY, K. S. The mechanism of vision: III The comparative visual acuity of pigmented and albino rats. Journal of Genetic Psychology, $1930,37,481-484$.

POWELL, R. W. Observational learning vs shaping: A replication. Psychonomic Science, 1968, 10 , 263.

POWELL, R.W., SAUNDERS, D., \& THOMPSON W. Shaping, auto-shaping and observational leaming with rats. Psychonomic Science, 1968, 13, 167-168.

\section{NOTES}

1. The authors wish to thank David French for help in collecting pilot data and David Fitzpatrick for the use of his equipment and laboratory space.

2. Now at the University of California, Berkeley, Calif. 94720.

3. Also at Research Department, Gateways Hospital, Los Angeles, Calif. 90026.

\title{
Two-way shuttle avoidance in wild and domesticated mice ${ }^{\prime}$
}

\section{ROBERT W. POWELL, University of South Florida, Tampa, Fla. 33620}

Two-way shuttle avoidance was studied in albino mice and wild beach mice. $A$ compound light-sound preaversive stimulus was employed. The albino mice more quickly reached a criterion of $90 \%$ avoidance than the wild mice, with the species has been questioned a number of times (Beach, 1950; Richter, 1959; Bitterman, 1960; Lockard, 1968). Lockard contends that the albino rat is the product of an environment in which the normal contingencies of survival do not obtain, and is, therefore, an unnatural species. While the major object of criticism has been the albino rat, the same objections would apply to other inbred domesticated laboratory species.

Several recent experiments have compared escape and avoidance learning in wild and domesticated species. Powell \& Morris (1968) employed operant-conditioning procedures to study escape, unsignaled and signaled avoidance in wild cotton rats (Sigmodon hispidus) and albino rats. They found that cotton rats initiated responding at lower shock intensities, but the albino rats displayed more effective asymptotic responding in all of the situations studied. Powell \& Peck (in press) compared running-wheel activity and unsignaled leverpress avoidance in Mongolian gerbils (Meriones unguiculatus) and albino rats. They also studied two-way shuttle avoidance in gerbils and albino mice. Rates of acquisition and asymptotic performance were quite similar in the different species. The gerbils ran at much higher rates than the rats. Boice, Denny, \& Thomas (1967) found no difference between mild Norway rats and albino rats in the acquisition of shuttle avoidance. The duration of the experiment (80 trials) and the curves presented indicated that asymptotic responding was not achieved.

The purpose of the present experiment was to provide additional comparative information on a wild and a domesticated species which are closely related on a phylogenetic basis. Albino mice (Mus musculus) and beach mice (Peromyscus polionotus), the two species studied, are both members of the order Rodentia and the suborder Myomorpha. The domesticated albino mouse has been developed from the common house mouse, which is a member of the family Muridae (old world rats and mice). The beach mouse belongs to the family Cricetidae (new world rats and mice). METHOD

Four adult male albino mice, Balb/c strain, and five adult male beach mice, all experimentally naive, served as Ss. The wild mice were first-generation offspring of field-caught Peromyscus. All animals had free access to water and Purina lab chow throughout the experiment.

A rectangular shuttlebox was employed which was constructed of $3 / 16$-in. Plexiglas. The four sides of the box were covered by heavy tape, so that light was admitted only through the top. The box was $17 \times 4 \times 4$ in. Compartments, $4 \times 4 \times 4$ in., could be formed at either end of the shuttlebox by 

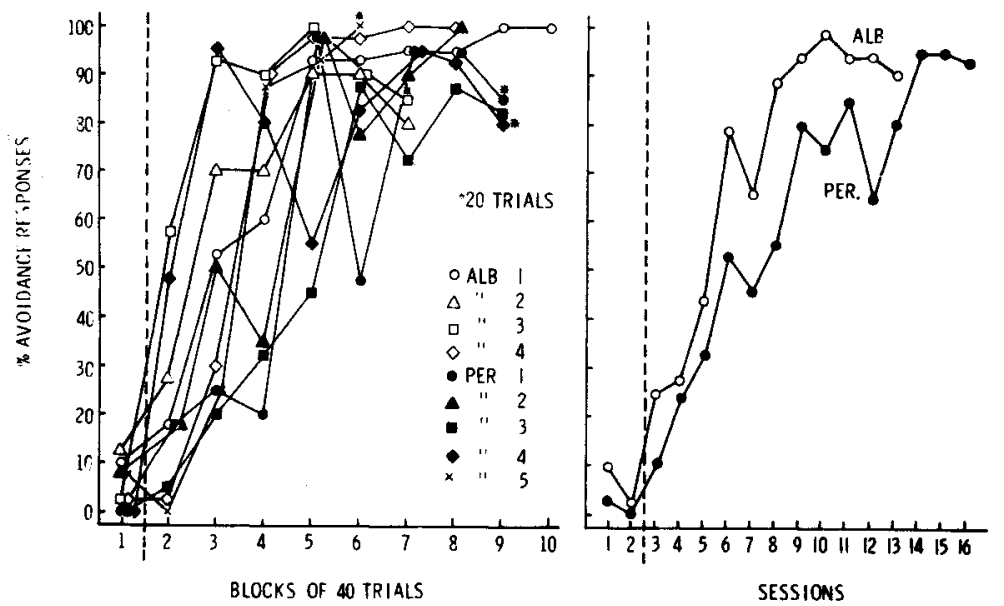

inserting wooden gates through apertures in the top of the box. Electric shock was delivered through a grid of $1 / 16$-in. stainless steel rods placed $1 / 8 \mathrm{in}$. apart. Shock was provided by a Lehigh Valley shock source, Model 1579A, and was scrambled to the grid. A Precision sine-square wave generator, Model E-310, was used to provide an auditory warning stimulus. The preshock stimulus complex consisted of three simultaneous events: (a) illumination of a 15-W bulb mounted in a movable wooden support 1 in. above the safe end of the box; (b) onset of a $5000 \mathrm{cps}(\mathrm{Hz})$ square-wave tone of approximately $85 \mathrm{~dB}$; and (c) withdrawal of the gate.

At the beginning of each session the animal was placed in one end of the shuttlebox with the gate closed. The box was placed so that all of it rested on the grid except 4 in. at the end opposite to where the animal was confined. This part rested on a wooden platform which was flush with the grid surface. Each trial consisted of the presentation of the preshock stimulus complex for $5 \mathrm{sec}$. If the animal did not run to the opposite end, so that all four feet were on the wooden platform, shock was presented. Shock intensity was $.30 \mathrm{~mA}$ for all Ss. The shock, light, and tone continued for $10 \mathrm{sec}$ or until the animal made the appropriate response. Whenever the animal made a correct response, the warning stimuli and shock, if present, were terminated. Following a trial, the gate was replaced so that the animal was confined in one of the end compartments. If the animal had made an avoidance or escape response and was, therefore, resting on the wooden platform, the entire shuttlebox was shifted 4 in. toward the end from which the animal had run. This had the effect of again placing the animal on the grid, while the opposite end compartment rested on the wooden plat- form. This manipulation was made approximately $15 \mathrm{sec}$ after each trial. All mice were tested for 20 trials a day with $90 \mathrm{sec}$ between trials. Training was continued to a criterion of 72 avoidances out of 80 trials over 4 successive days. Animals which met this criterion quickly were studied over additional trials. Response latencies were timed by a Standard Electric Time Co. running time meter. The experiment began with two control sessions for each animal. The control sessions were identical to the training sessions, except that no shock was presented.

\section{RESULTS AND DISCUSSION}

The results are summarized in Fig. 1, where group curves are presented in addition to the curves for individual Ss. All animals met the avoidance criterion except Peromyscus No. 3. This animal was studied for 320 conditioning trials, during which its peak avoidance was $85 \%$ over 80 trials. This is just below criterion. The remaining Peromyscus required $160,260,280$, and 280 conditioning trials, respectively, to achieve criterion, while the albino mice required $120,160,180$, and 180 trials to criterion, respectively. Analysis of variance of the number of avoidance responses per session for each mouse revealed a difference between the groups which was significant at the .05 level $(\mathrm{F}=5.78, \mathrm{df}=1 / 123)$.

A major difference between species was that the Peromyscus displayed more session-to-session variability in performance than the albino mice. Kavanau (1967) also noted a high degree of behavioral variability in his comprehensive studies with Peromyscus. He surmised that a certain degree of behavioral variability would have adaptive value in the wild. Kavanau theorized that the relatively uniform behavior of inbred strains may represent only a small fragment of the total response spectrum for the species and,
Fig. 1. Individual learning curves are presented for each mouse in the left panel, with group curves presented in the right panel. The group curve for the Perom yscus is based on the data for four animals from Days 10 to 14. The data for individual mice have been averaged over two sessions to facilitate presentation.

thus, could have minimal significance for survival in the wild.

The present results show that wild mice require significantly more conditioning trials than albino mice to reach a predetermined avoidance criterion, but the asymptotic performance of the two species is quite similar. Observations during the experiment suggest that the Peromyscus are affected more by nonexperimental stimuli than are the albino mice. If this hypothesis is correct, the use of more potent stimuli, such as higher shock intensities, would be required with the wild mice in order to produce motivational states which engender optimal performance. While this procedure was not employed in the present experiment, studies of unsignaled lever-press avoidance in wild black rats (Rattus rattus) and wild cotton rats (Sigmodon hispudus), which are currently in progress in this laboratory, have shown that it is usually necessary to use very high shock intensities $(3.5-8.0 \mathrm{~mA})$ to produce effective avoidance. The same animals perform erratically when lower shock intensities are used.

\section{REFERENCES}

BEACH, F. A. The snark was a boojum. American Psychologist, 1950, 5, 115-124.

BITTERMAN, M. E. Toward a comparative psychology of learning. American Psychologist, 1960, 15, 704-712.

BOICE, R., DENNY, R. M., \& EVANS, T. A comparison of albino and wild rats in shuttlebox avoidance. Psychonomic Science, 1967, 8, 271-272.

KAVANAU, L. Behavior of captive white footed mice. Science, 1967, 155, 1623-1629.

LOCKARD, R. B. The albino rat: A defensible choice or a bad habit? American Psychologist, $1968,23,734-742$.

POWELL, R. W., \& MORRIS, G. A comparison of escape and avoidance conditioning in wild and domesticated rats. Journal of the Experimental Analysis of Behavior, 1968, 11, 473-478.

POWELL, R. W., \& PECK, S. Running-wheel activity and avoidance in the Mongolian gerbil. Journal of the Experimental Analysis of Behavior, in press.

RICHTER, C. P. Rats, man, and the welfare state. American Psychologist, 1959, 14, 18-28. NOTE

1. This research was supported in part by a grant from the University of South Florida Research Council. Reprints may be obtained from the author, Department of Behavioral Science, University of South Florida, Tampa, Florida 33620. 